\title{
Editorial
}

\section{Seeing the Forest and the Trees: Research on Plant Science Teaching and Learning}

\author{
Diane Ebert-May* and Emily Holt ${ }^{\dagger}$
}

\author{
${ }^{*}$ Department of Plant Biology, Michigan State University, East Lansing, MI 48824; ${ }^{\dagger}$ Department of Biology, Utah \\ Valley University, Orem, UT 84058
}

Welcome to this special focus section of CBE-Life Sciences Education. A large portion of this issue is dedicated to investigations that explore how students think about plants and how faculty teach about plants. To date, people with an interest in studying plant science teaching and learning have limited journals for publishing their scholarly work. The call for contributions to this section was intended to attract authors and readers with an interest in plant science education. During the peer review process, one criterion for selection of papers required that the work provided insight into student learning focused specifically on plants. So, if plants were used as a possible example rather than as a focal point of learning, the paper was not considered appropriate for this section. Some very good instruction makes use of plants as examples, but we wanted to highlight learning challenges and opportunities unique to teaching and learning about plants.

Plants have long inspired influential individuals (e.g., Robert Hooke, Carl Linnaeus, Charles Darwin, Gregor Mendel, Barbara McClintock) whose contributions to science extend far beyond their botanical training. Today, one tiny mustard, Arabidopsis thaliana, has taken the world by storm. Uniting researchers across the globe, Arabidopsis transcends a model and has become the reference organism addressing major questions in plant biology in less than a quarter century. It has ushered in an explosion of molecular data as the first plant to have its entire genome sequenced; and it has served as the cornerstone for biotechnological applications with plants. Furthermore, Arabidopsis has been used in classrooms to improve learning of genetics (Zheng, 2007), evolution (Wyatt and Ballard, 2007), and biotechnology (Barnard et al., 2006),

DOI: $10.1187 /$ cbe.14-06-0105

Address correspondence to: Diane Ebert-May (ebertmay@msu.edu).

(C) 2014 D. Ebert-May and E. Holt. CBE-Life Sciences Education (C) 2014 The American Society for Cell Biology. This article is distributed by The American Society for Cell Biology under license from the author(s). It is available to the public under an AttributionNoncommercial-Share Alike 3.0 Unported Creative Commons License (http:/ / creativecommons.org/licenses/by-nc-sa/3.0).

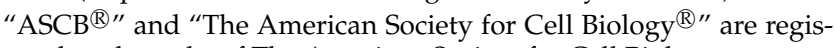
tered trademarks of The American Society for Cell Biology. and to promote student research experiences (Dolan et al., 2008; Burnette and Wessler, 2013).

Beyond this single species, plants represent a system that does much more than photosynthesis, which is often the only plant concept taught in introductory courses. Research on plant systems is expanding, with implications for human health and ecosystem services-from climate change and bioenergy to drug discovery and food science. Plants do many interesting things at multiple scales that include, to mention a few, complex secondary metabolism, gene regulation, genomic evolution (while animals simply move in response to their environment), and carbon fixation for biomass to feed the world. We must move plant science education into the 21st century. Thinking of plants at multiple scales requires understanding of core ideas (evolution and ecology), crossdisciplinary concepts (matter and energy), and use of science practices (models, arguments, and cooperative work).

Using plant systems can help transform traditional descriptive botany courses into fully integrated plant science, while not losing the "trees in the forest." For example, we posit that learning the names of plants is not simply memorization; rather, the knowledge and skills gained through this process can promote inquiry into community structure and function and foster an intimacy between a student and nature. On the practical side, compared with animals, plants are often less expensive, more scalable, and more flexible in the classroom, owing to the short generation time of some species and ease of avoiding ethical and safety constraints. Despite the accessibility of plants in promoting education in the sciences, research on curriculum and cognition clearly illustrates considerable bias by students and faculty in favor of their mobile, heterotrophic counterparts.

This special section attempts to highlight several types of research in plant sciences education. Three of these six articles report on original inquiry-based instructional materials to teach about what determines variation in phenotype, focusing on the inheritance and expression of quantitative traits using plants (Batzli et al.); how students connect science practices, explanations, and arguments from evidence about plant metabolism and growth (Dauer et al.); and the use of a computer-based program to learn plant identification (Kirchoff et al.). Two articles explore the conceptual foundations 
of "plant blindness" — the idea that students fail to notice or appreciate plants-among young children (Anderson et al.) and university students (Balas and Momsen). The final article reports how the infusion of plant-based research into majors' courses affects students' conceptual understanding, abilities to conduct and communicate research, and interest in plant science (Ward et al.).

We hope this body of work is both enjoyable and inspirational, promoting ideas for transformation of courses and stimulating future research. Often, animal or bacterial systems are taught as the exemplar, and students are expected to transfer that knowledge to plant systems. We assert that learning concepts about plant systems first may benefit students in two ways. First, due to their aforementioned unique properties (e.g., autotrophy), we propose that the knowledge and practices students gain from studying plant systems may be more portable into simpler heterotrophic systems, rather than vice versa. Second, using plants as the standard to teach basic biological principles may also combat documented "plant blindness." This leads to the questions: What about plant science learning is transferable? How does transformed course design influence students' understanding of plant concepts and science practices? The field is wide open for rich descriptions about implementation of plant science curricula and, importantly, evaluation of educational innovations. Does course transformation focused on plant science make a difference? What can students do better now than they did before? Finally, plant blindness exists-we need to know the cognitive underpinnings and instructional design that enables students to "see" plants and their applications and implications.

\section{REFERENCES}

Barnard B, Sussman M, Splinter BonDurant S, Nienhuis J, Krysan P (2006). Microarrays (DNA chips) for the classroom laboratory. Biochem Mol Biol Educ 34, 355-359.

Burnette JM, Wessler SR (2013). Transposing from the laboratory to the classroom to generate authentic research experiences for undergraduates. Genetics 193, 367-375.

Dolan EL, Lally DJ, Brooks E, Tax FE (2008). PREPping students for authentic science. Sci Teach 75, 38-43.

Wyatt S, Ballard HE (2007). Arabidopsis ecotypes: a model for course projects in organismal plant biology and evolution. Am Biol Teach $69,477-481$.

Zheng Z-L (2007). Use of the gl1 mutant and the CA-rop2 transgenic plants of Arabidopsis thaliana in the biology laboratory course. Am Biol Teach 68, e148-e153. 